\section{Paclobutrazol Pre-plant Bulb Dips Effectively Control Height of 'Nellie White' Easter Lily}

\author{
Christopher J. Currey ${ }^{1}$ and Roberto G. Lopez ${ }^{1,2}$
}

AdDITIONAL INDEX wORDs. Bonzi, Lilium longiflorum, plant growth regulator, PGR

SUMMARY. The influence of pre-plant bulb dips in paclobutrazol solutions on final plant height, days to flower, and flower bud number were evaluated for easter lily (Lilium longiflorum). 'Nellie White' easter lily bulbs were placed in solutions of paclobutrazol containing $0,30,60$, or $120 \mathrm{mg} \cdot \mathrm{L}^{-1}$ for 15 min preceding planting. Days to flower and flower bud number were unaffected by paclobutrazol. Plant height at flowering for bulbs dipped in paclobutrazol solutions was $15 \%$ to $26 \%$ shorter compared with untreated bulbs. Additionally, dipping bulbs in $120 \mathrm{mg} \cdot \mathrm{L}^{-1}$ paclobutrazol resulted in plants that met target height specifications for commercially grown easter lily. Based on these results, dipping easter lily bulbs in paclobutrazol solutions can be an effective strategy for reducing stem elongation without negatively impacting days to flower or flower bud number for commercially grown easter lily.

$\mathrm{E}$ aster lily is an important flowering potted crop in the United States, with a wholesale value over \$26 million for the 15 largest-producing states (U.S. Department of Agriculture, 2007). Plant height can reach up to $1 \mathrm{~m}$ and must be controlled to produce plants 48 to $56 \mathrm{~cm}$ tall for aesthetic value and amenability for packing and shipping (Miller, 1992, 1993).

Height control of easter lily may be achieved environmentally, culturally, or chemically (Blom et al., 1995, 2004; Erwin et al., 1989; McAvoy, 2001). Stem elongation may be reduced environmentally by manipulating the difference between the day and night air temperatures-also known as DIF (Erwin et al., 1989). Increasing light intensity and reducing exposure to far-red-enriched light at the end of the day (twilight) are additional environmental techniques for reducing easter lily stem

We gratefully acknowledge Diane Camberato, Jessie Heller, Rob Eddy, and Dan Hahn for greenhouse assistance, funding from growers providing support for Purdue University floriculture research, and support from the Purdue Agricultural Experiment Station

We thank the Easter Lily Research Foundation and Fred C. Gloeckner \& Co., Inc. for bulbs, Premier Horticulture for growing media, Scotts Co. for fertilizer, and ITML for pots.

The use of trade names in this publication does not imply endorsement by Purdue University of products named nor criticism of similar ones not mentioned.

${ }^{1}$ Department of Horticulture and Landscape Architecture, Purdue University, West Lafayette, IN 47907-2010

${ }^{2}$ Corresponding author. E-mail: rglopez@purdue. edu. elongation (Blom et al., 1995). Reduction of easter lily stem elongation may be achieved culturally with overhead irrigation using cold water from shoot emergence to flowering (Blom et al., 2004). While these environmental and cultural techniques may be used during easter lily production, they may be difficult to employ in greenhouses with multiple crops or limited infrastructure. Alternatively, chemical plant growth retardant (PGR) applications may used to produce compact potted easter lilies (McAvoy, 2001).

Several PGRs have been reported to produce shorter easter lilies, including ancymidol, ethephon, paclobutrazol, and uniconazole (Bailey and Miller, 1989; Gianfagna and Wulster, 1986; Jiao et al., 1986; Larson et al., 1987; Lewis and Lewis, 1980, 1981, 1982; Sanderson et al., 1975; Wilfret, 1987, 1990; Wilfret and Reiser, 1996). While PGRs are commonly applied as sprays or media drenches, bulb crops may be submerged in PGR solutions before planting (bulb dip). Bulb dips can reduce labor costs and avoid reduced efficacy associated with drench applications to substrate components, including bark (Barrett, 2001; Miller, 1993).

Bulb dips have been reported to be an effective method of applying PGRs to control height of numerous bulb crops, including hyacinth ( Hyacinthus), paperwhites (Narcissus), and tulips (Tulipa) (Krug et al., 2005a, 2005 b, 2006). Easter lily height also has been successfully suppressed in response to bulb dips, yet only solutions containing ancymidol or uniconazole have been used (Larson et al., 1987; Lewis and Lewis, 1980, 1981, 1982; Wilfret, 1990). Paclobutrazol has effectively reduced easter lily stem elongation when applied as a drench or spray (Gianfagna and Wulster, 1986; Jiao et al., 1986; Wilfret, 1987; Wilfret and Reiser, 1996). Dipping oriental lily (Lilium auratum $\times$ Lilium speciosum) and LA-hybrid lily (L. longiflorum $\times$ asiatic Lilium spp.) bulbs in paclobutrazol solutions has successfully controlled plant height (Francescangeli et al., 2007; Ranwala et al., 2002, 2005); however, we have found no reports of dipping easter lily bulbs in paclobutrazol solutions.

Our objectives in this study were to determine if dipping 'Nellie White' easter lily bulbs in paclobutrazol solutions would suppress final plant height and produce a commercially acceptable plant while not adversely impacting days to flower and flower bud number.

\section{Materials and methods}

On 27 Oct. 2008, 200 25- to 30-cm-circumference 'Nellie White' easter lily bulbs were delivered from the Easter Lily Research Foundation (Harbor, OR) to Purdue University in West Lafayette, IN (lat. $40^{\circ} \mathrm{N}$ ), in pressboard cases filled with peatmoss. The cases were immediately placed in a walk-in environmental cooler set at $5{ }^{\circ} \mathrm{C}$ for a 6 -week vernalization treatment. On 9 Dec. 2008, cases were removed from the cooler and the peat

\begin{tabular}{llll}
\hline $\begin{array}{l}\text { Units } \\
\text { To convert U.S. to SI, } \\
\text { multiply by }\end{array}$ & U.S. unit & SI unit & $\begin{array}{l}\text { To convert SI to U.S., } \\
\text { multiply by }\end{array}$ \\
\hline 3.7854 & gal & $\mathrm{L}$ & 0.2642 \\
2.54 & inch $(\mathrm{es})$ & $\mathrm{cm}$ & 0.3937 \\
28,350 & $\mathrm{Oz}$ & $\mathrm{mg}$ & $3.5274 \times 10^{-5}$ \\
1 & $\mathrm{ppm}$ & $\mathrm{mg} \cdot \mathrm{L}^{-1}$ & 1 \\
0.001 & $\mathrm{ppm}$ & $\mathrm{mL} \cdot \cdot^{-1}$ & 1000 \\
$\left({ }^{\circ} \mathrm{F}-32\right) \div 1.8$ & ${ }^{\circ} \mathrm{F}$ & ${ }^{\circ} \mathrm{C}$ & $\left(1.8 \times{ }^{\circ} \mathrm{C}\right)+32$
\end{tabular}


was gently removed as 40 uniform bulbs were selected. Ten bulbs were placed in each of $4 \mathrm{~L}$ of solution containing 30,60 , or $120 \mathrm{mg} \cdot \mathrm{L}^{-1}$ paclobutrazol (Bonzi; Syngenta Crop Protection, Greensboro, NC) or $4 \mathrm{~L}$ of reverse-osmosis water (control) for $15 \mathrm{~min}$ to promote uptake of solution and were then allowed to drain for $1 \mathrm{~h}$. All bulbs were planted directly into $15-\mathrm{cm}$-diameter standard round plastic containers (1.6 L volume) filled with a commercial soilless medium composed of Canadian sphagnum peat, horticultural perlite, and vermiculite (ProMix-BX; Premier Horticulture, Quakertown, PA). Plants were irrigated as necessary with acidified water supplemented with $15 \mathrm{~N}-2.2 \mathrm{P}-12.5 \mathrm{~K}$ water-soluble fertilizer (Excel Cal-Mag; Scotts, Marysville, $\mathrm{OH}$ ) to provide the following (in $\mathrm{mg} \cdot \mathrm{L}^{-1}$ ) at each irrigation: 200 nitrogen, 29 phosphorous, 167 potassium, 67 calcium, 1.0 iron, 1.0 copper, 0.5 manganese, 0.5 zinc, 0.2 boron, and 0.1 molybdenum. Irrigation water was supplemented with 93\% sulfuric acid (Ulrich Chemical, Indianapolis) at $0.08 \mathrm{~mL} \cdot \mathrm{L}^{-1}$ to reduce alkalinity to $100 \mathrm{mg} \cdot \mathrm{L}^{-1}$ and $\mathrm{pH}$ to a range of 5.7 to 6.0 .

The plants were grown in a glassglazed greenhouse with exhaust fan and evaporative-pad cooling, radiant hot-water heating, and retractable shade curtains controlled by an environmental computer (Maximizer Precision 10; Priva Computers, Vineland Station, ON, Canada). The greenhouse temperature set point was $18 \pm$ $1{ }^{\circ} \mathrm{C}$ with a 16 -h photoperiod $(0600-$ $2200 \mathrm{HR}$ ) consisting of natural daylengths with day-extension lighting $\left(\approx 2 \mu \mathrm{mol} \cdot \mathrm{m}^{-2} \cdot \mathrm{s}^{-1}\right.$ at canopy level $)$ from 1700 to 2000 HR with incandescent lamps. High-pressure sodium lamps delivered a supplemental photosynthetic photon flux (PPF) of 100 $\mu \mathrm{mol} \cdot \mathrm{m}^{-2} \cdot \mathrm{s}^{-1}$ at plant height [as measured with a light quantum sensor (LICOR Biosciences, Lincoln, NE)] when the ambient greenhouse daily light integral was $<10 \mathrm{~mol} \cdot \mathrm{m}^{-2} \cdot \mathrm{d}^{-1}$. Environmental data are reported in Table 1.

Plant height was recorded at emergence and weekly thereafter, and treatment averages were plotted (Fig. 1) on graphical tracking software (Heins et al., 1987). At visible anthesis (flowering), the number of flower buds and final plant height were recorded. Days to flower were calculated for each plant. There were 10 replicates (bulbs) per treatment. A completely randomized design was used. Data were analyzed with the SAS (version 9.1; SAS Institute, Cary, NC) mixed model procedure (PROC MIXED), and pairwise comparisons between treatments were performed using Tukey's honestly significant difference (HSD) test at $P \leq 0.05$.

\section{Results and discussion}

Plant height was shorter for all paclobutrazol-treated bulbs compared with control plants (Table 2 ). Height at flowering was suppressed by $15 \%$ to $26 \%$ compared with control plants as paclobutrazol concentration increased from 30 to $120 \mathrm{mg} \cdot \mathrm{L}^{-1}$ (Table 2). Soaking bulbs in a 120 $\mathrm{mg} \cdot \mathrm{L}^{-1}$ paclobutrazol solution resulted in plants that were $54.6 \mathrm{~cm}$ tall at flowering (Table 2), which met the target height range of 48 to $56 \mathrm{~cm}$ for potted, flowering easter lily (Miller, 1992). Neither days to flower nor flower bud number were affected by paclobutrazol applications (Table 2). Our results on the impact of paclobutrazol on height, days to flower, and flower bud number are in agreement with previous work using paclobutrazol sprays or drenches with easter lily, or paclobutrazol bulb dips with hybrid lilies (Francescangeli et al., 2007; Gianfagna and Wulster, 1986; Jiao et al., 1986; Ranwala et al., 2002; Wilfret, 1987; Wilfret and Reiser, 1996).

Although paclobutrazol has been applied to easter lily, it has been applied as foliar sprays and media drenches (Gianfagna and Wulster, 1986; Jiao et al., 1986; Wilfret, 1987; Wilfret and Reiser, 1996). Gianfagna and Wulster (1986) demonstrated that paclobutrazol drench applications affected 'Ace' and 'Nellie White' easter lily differently. Paclobutrazol had no effect on final height or number of flowers per plant of 'Nellie White', yet the number of days to anthesis was reduced by 3.9 and 6.0 when 1.0 or $2.5 \mathrm{mg} /$ pot was applied (Gianfagna and Wulster, 1986). The number of flowers per plant and number of days

Table 1. Mean greenhouse air temperature and daily light integral (DLI) during each month for 'Nellie White' easter lilies grown from bulbs left untreated (control) or soaked in paclobutrazol solutions preceding planting.

\begin{tabular}{lcc}
\hline Month & $\begin{array}{c}\text { Temp }[\text { mean } \\
\left. \pm \mathrm{SD}\left({ }^{\circ} \mathbf{C}\right)\right]^{\mathrm{z}}\end{array}$ & $\begin{array}{c}\text { DLI } \\
\left(\mathbf{m o l} \cdot \mathbf{m}^{-2} \cdot \mathbf{d}^{-1}\right)\end{array}$ \\
\hline December & $16.9 \pm 1.2$ & 8.4 \\
January & $17.1 \pm 0.9$ & 9.2 \\
February & $18.2 \pm 1.0$ & 10.0 \\
March & $18.8 \pm 1.0$ & 14.3 \\
April & $18.8 \pm 0.6$ & 18.9 \\
\hline
\end{tabular}

${ }^{\mathrm{z}}\left(1.8 \times{ }^{\circ} \mathrm{C}\right)+32={ }^{\circ} \mathrm{F}$

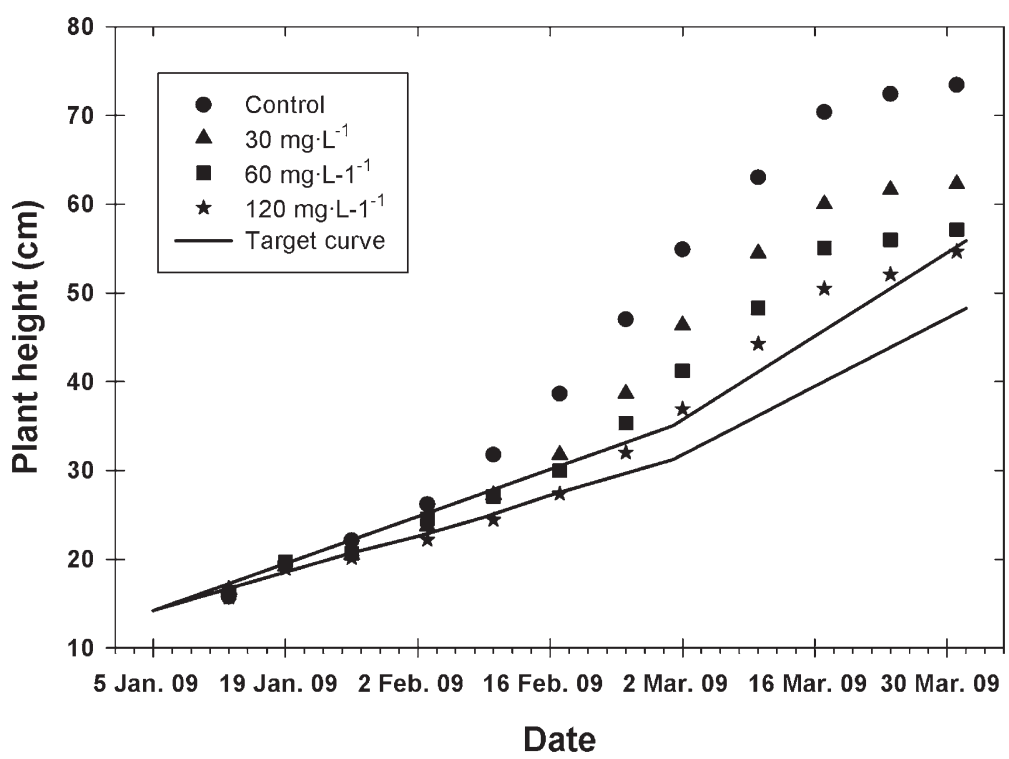

Fig. 1. Graphical tracking chart displaying the minimum and maximum target heights (solid lines) and weekly average heights of 'Nellie White' easter lily from untreated (control) bulbs or bulbs soaked in paclobutrazol solutions containing 30 , 60 , or $120 \mathrm{mg} \cdot \mathrm{L}^{-1}(\mathrm{ppm})$ for $15 \mathrm{~min}$ preceding planting $(1 \mathrm{~cm}=0.3937 \mathrm{inch})$. 
Table 2. The effects of soaking 'Nellie White' easter lily bulbs left untreated (control) or soaked in paclobutrazol solutions containing 30,60 , or $120 \mathrm{mg} \cdot \mathrm{L}^{-1}$ for $15 \mathrm{~min}$ preceding planting on final plant height, days to flower, and flower bud number.

\begin{tabular}{lcccc}
\hline Plant growth retardant & Concn $\left(\mathbf{m g} \cdot \mathbf{L}^{-1}\right)^{\mathrm{z}}$ & Final plant ht $(\mathbf{c m})^{\mathrm{z}}$ & Time to flower $(\mathbf{d})$ & Flower buds $(\mathbf{n o})$ \\
\hline Control & - & $73.5 \mathrm{a}^{\mathrm{y}}$ & $111 \mathrm{a}$ & $5.5 \mathrm{a}$ \\
Paclobutrazol & 30 & $62.3 \mathrm{~b}$ & $108 \mathrm{a}$ & $5.3 \mathrm{a}$ \\
Paclobutrazol & 60 & $57.1 \mathrm{bc}$ & $109 \mathrm{a}$ & $5.4 \mathrm{a}$ \\
Paclobutrazol $^{\text {Significance }}$ & 120 & $54.6 \mathrm{c}$ & $112 \mathrm{a}$ & $4.5 \mathrm{a}$ \\
\hline
\end{tabular}

${ }^{\mathrm{z}} 1 \mathrm{mg} \cdot \mathrm{L}^{-1}=1 \mathrm{ppm}, 1 \mathrm{~cm}=0.3937$ inch.

'Within-column means followed by different letters are significantly different by Tukey's honestly significant difference (HSD) test at $P \leq 0.05$.

${ }^{\mathrm{N} S},{ }^{*},{ }^{* *},{ }^{* *}$ indicates not significant or significant at $P \leq 0.05,0.01$, or 0.001 , respectively.

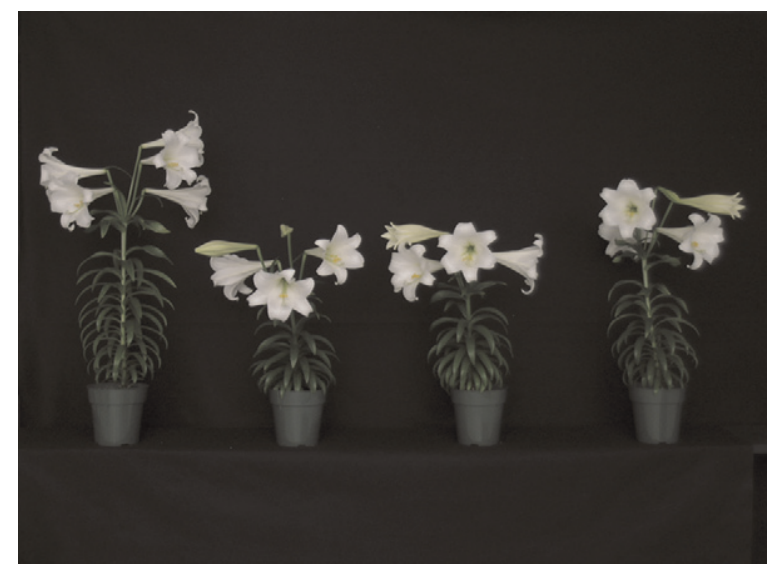

Fig. 2. Flowering 'Nellie White' easter lily from bulbs left untreated (control) or soaked in paclobutrazol solutions containing 120,60 , or $30 \mathrm{mg} \cdot \mathrm{L}^{-1}(\mathrm{ppm})$ for 15 min preceding planting.

to anthesis of 'Ace' were unaffected by paclobutrazol, although treated plants were $29 \%$ to $44 \%$ shorter than untreated plants as drench concentration increased from 5.0 to $20.0 \mathrm{mg} /$ pot (Gianfagna and Wulster, 1986). Jiao et al. (1986) reported that applying 2.0 to $6.0 \mathrm{mg} /$ pot paclobutrazol suppressed 'Nellie White' plant height by $19 \%$ to $42 \%$ compared with untreated plants, but did not affect days to flower or flower number. Applying 2.0 or $4.0 \mathrm{mg} /$ pot paclobutrazol drenches reduced stem elongation of 'Ace' and 'Nellie White' by $25 \%$ or $39 \%$ and $16 \%$ or $25 \%$, respectively, while spraying 2.0 or $4.0 \mathrm{mg} /$ pot reduced stem elongation of 'Ace' and 'Nellie White' by $13 \%$ or $23 \%$ and $7 \%$ or $12 \%$, respectively, though neither days to flower or number of flowers of both cultivars was affected by paclobutrazol applications (Wilfret, 1987). Applying media drenches supplying $2.0,3.0$, or $4.0 \mathrm{mg} /$ pot paclobutrazol to 'Nellie White' produced plants $19 \%$, $27 \%$, or $36 \%$ shorter compared with untreated plants, but had no effect on days to flower or flower number (Wilfret and Reiser, 1996). Applying an additional 1.0 or 2.0 $\mathrm{mg} /$ pot paclobutrazol at floral bud emergence or floral bud stretch to pots already treated with $2.0 \mathrm{mg} /$ pot further reduced plant height (Wilfret and Reiser, 1996). When taken together with our work, it appears that paclobutrazol can effectively control easter lily height without adversely impacting days to flower or flower number, regardless of application method.

Our results are similar to those using paclobutrazol bulb dips for oriental and LA-hybrid lilies (Francescangeli et al., 2007; Ranwala et al., 2002). Ranwala et al. (2002) demonstrated that dipping bulbs in 50 to 300 ppm paclobutrazol solutions was effective in suppressing height for 14 oriental hybrid and LA-hybrid lilies, although the concentration required for height suppression varied with cultivar. Flowering was delayed up to $4 \mathrm{~d}$ for 'Casa Blanca' dipped in 200 or 300 $\mathrm{mg} \cdot \mathrm{L}^{-1}$, yet most cultivars were unaffected by paclobutrazol; flower number of any cultivar was unaffected by paclobutrazol (Ranwala et al., 2002). Final height of 'Ercolano' and 'Royal Prospect' LA-hybrid lily was $29 \%$ to $45 \%$ and $45 \%$ to $59 \%$ shorter, respectively, compared with untreated plants as paclobutrazol concentration increased from 50 to $150 \mathrm{ppm}$. Days to flower of 'Ercolano' was unaffected by treatment, and while soaking 'Royal Prospect' bulbs in 150 ppm paclobutrazol did significantly delay days to first open flower by one day compared with untreated plants, this does not have much commercial significance (Francescangeli et al., 2007). The number of flower buds of 'Ercolano' and 'Royal Prospect' were unaffected by any treatment (Francescangeli et al., 2007). These results, combined with our findings, indicate that paclobutrazol bulb dips are an effective method of controlling height of oriental, LAhybrid, and easter lilies.

\section{Conclusions}

Paclobutrazol is effective in reducing stem elongation of 'Nellie White' easter lily when applied as a bulb dip. Additionally, bulbs dipped in $120 \mathrm{mg} \cdot \mathrm{L}^{-1}$ paclobutrazol for 15 min flowered within the commercially acceptable specified range of heights without affecting the days to flower or flower bud number (Fig. 2). Applying paclobutrazol to easter lily bulbs using a bulb dip can reduce labor and chemical costs when compared with spraying plants or drenching media. Producers may want to conduct onsite trials, as Larson et al. (1987) has demonstrated that duration of the dip, concentration of a.i., and cultivar can affect height, days to flower, and flower number.

\section{Literature cited}

Bailey, D.A. and W.B. Miller. 1989. Whole-plant response of easter lily to ancymidol and uniconazole. J. Amer. Soc. Hort. Sci. 114:393-396. 
Barrett, J. 2001. Mechanisms of action, p. 32-41. In: M.L. Gaston, P. Konjoian, L.A. Kunkle, and M.F. Wilt (eds.). Tips on regulating growth of floriculture crops. O.F.A. Services, Columbus, OH.

Blom, T.J., D. Kerec, W. Brown, and D. Kristie. 2004. Irrigation method and temperature of water affect height of potted easter lilies. HortScience 39:71-74.

Blom, T.J., M.J. Tsujita, and G.L. Roberts. 1995. Far-red at end of day and reduced irradiance affect plant height of easter and hybrid lilies. HortScience 30:1009-1012.

Erwin, J.E., R.D. Heins, and M.G. Karlsson. 1989. Thermomorphogenesis in Lilium longiflorum. Amer. J. Bot. 76:47-52.

Francescangeli, N., P. Marinangeli, and N. Curvetto. 2007. Paclobutrazol for height control of two Lilium L.A. hybrids grown in pots. Span. J. Agr. Res. 5:425430 .

Gianfagna, T.J. and G.J. Wulster. 1986. Comparative effects of ancymidol and paclobutrazol on easter lily. HortScience 21:463-464.

Heins, R.D., J. Erwin, M. Karlsson, R. Berghage, W. Carlson, and J. Biernbaum. 1987. Tracking easter lily height with graphs. Easter lily response to temperature, Part 2. GrowerTalks 51(8):64-68.

Jiao, J., M.J. Tsujita, and D.P. Murr. 1986. Effects of paclobutrazol and A-rest on growth on growth, flowering, leaf carbohydrate and leaf senescence in Nellie White easter lily (Lilium longiflorum Thunb.). Scientia Hort. 30:135-141.

Krug, B.A., B.E. Whipker, I. McCall, and J.M. Dole. 2005a. Comparison of flurpri- midol to ancymidol, paclobutrazol, and uniconazole for tulip height control. HortTechnology 15:370-373.

Krug, B.A., B.E. Whipker, I. McCall, and J.M. Dole. 2005b. Comparison of flurprimidol to ethephon, paclobutrazol, and uniconazole for hyacinth height control. HortTechnology 15:872-874.

Krug, B.A., B.E. Whipker, I. McCall, and J.M. Dole. 2006. Narcissus response to plant growth regulators. HortTechnology 16:129-132.

Larson, R.A., C.B. Thorne, R.R. Milks, Y.M. Isenberg, and L.D. Brison. 1987. Use of ancymidol bulb dips to control stem elongation of easter lilies grown in a pine bark medium. J. Amer. Soc. Hort. Sci. 112:773-777.

Lewis, A.J. and J.S. Lewis. 1980. Response of Lilium longiflorum to ancymidol bulb dips. Scientia Hort. 13:93-97.

Lewis, A.J. and J.S. Lewis. 1981. Improving ancymidol efficiency for height control of easter lily. HortScience 16:89-90.

Lewis, A.J. and J.S. Lewis. 1982. Height control of Lilium longiflorum Thunb. 'Ace' using ancymidol bulb-dips. HortScience 17:336-337.

McAvoy, R. 2001. Easter lilies, p. 74-78. In: M.L. Gaston, P. Konjoian, L.A. Kunkle, and M.F. Wilt (eds.). Tips on regulating growth of floriculture crops. O.F.A. Services, Columbus, $\mathrm{OH}$.

Miller, W.B. 1992. Easter and hybrid lily production. Timber Press, Portland, OR.

Miller, W.B. 1993. Lilium longiflorum, p. 391-422. In: A. DeGertog and M.
LeNard (eds.). The physiology of flowering bulbs. Elsevier, Amsterdam, The Netherlands.

Ranwala, A.P., G. Legnani, M. Reitmer, B.B. Stewart, and W.B. Miller. 2002. Efficacy of plant growth retardants as preplant bulb dips for height control in LA and oriental hybrid lilies. HortTechnology 12:426-431.

Ranwala, N.K., A.P. Ranwala, and W.B. Miller. 2005. Paclobutrazol and uniconazole solutions maintain efficacy after multiple lily bulb dip events. Hort Technology 15:551-553.

Sanderson, K.C., W.C. Martin, Jr., K.A. Marcus, and W.E. Goslin. 1975. Effects of plant growth retardants on Lilium longiflorum Thunb. cv. Georgia. HortScience 10:611-613.

Wilfret, G.J. 1987. Height retardation of easter lilies grown in containers. Proc. Florida State Hort. Soc. 100:379-382.

Wilfret, G.J. 1990. Effect of preplant bulb soak with ancymidol or uniconazole on growth and development of easter lily. Proc. Florida State Hort. Soc. 103:203206.

Wilfret, G.J. and R.A. Reiser. 1996. Effect of late growth regulator applications at floral bud emergence and stretch on easter lily development. Proc. Florida State Hort. Soc. 109:11-14.

U.S. Department of Agriculture. 2007. Floriculture and nursery crops yearbook: Report. 9 Sept. 2009. <http://www.ers. usda.gov/Publications/Flo/2007/09Sep/ FLO2007.pdf>. 